
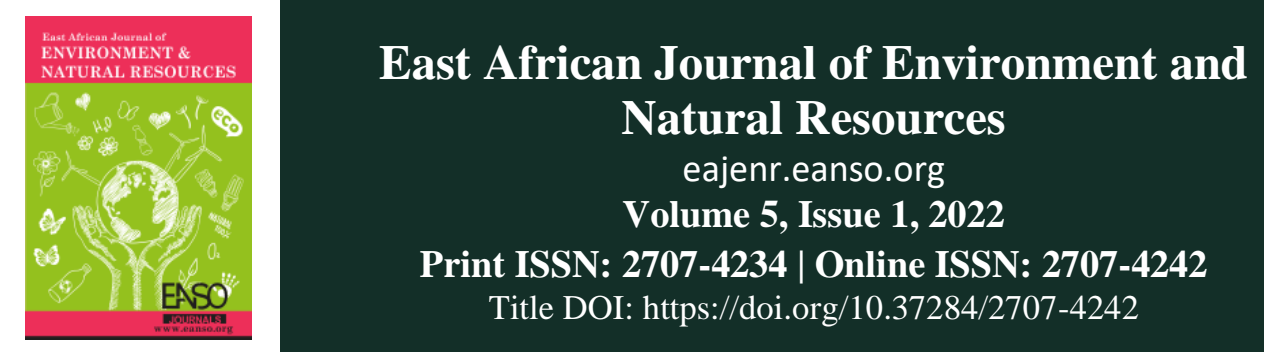

Original Article

\title{
Assessment of Heavy Metals Contamination of Surface Dust from Waste Electrical and Electronic Equipment at Odogbolu Local Government Area of Ogun State in Southwestern Nigeria.
}

\author{
Rasaki Kolawole Odunaike ${ }^{1}$, Adetoro Temitope Talabi ${ }^{1}{ }^{*}, J_{\text {ohn Abidemi Laoye }}{ }^{1}$, Lukman Popoola \\ Akinyemi $^{1} \&$ Mary Feranmi Obasan ${ }^{1}$ \\ ${ }^{1}$ Olabisi Onabanjo University, P.M.B. 2002, Ago-Iwoye, Ogun State. Nigeria. \\ *Correspondence email: talabi.adetoro@oouagoiwoye.edu.ng.
}

Article DOI: https://doi.org/10.37284/eajenr.5.1.546

\section{Date Published: ABSTRACT}

09 February 2022 In developing countries, electronic waste is a subject of concern in the environmental challenge due to the import of electronics that are not useful from developed

Keywords: countries. The developed country exports the waste as a source of donation to the

Heavy Metals, metals which are harmful to human health. This research work assessed electronic

Electronic dumpsite to detect the concentrations of heavy metals present in the soil and around

Waste, the dumpsites. Three dumpsites were considered in the Odogbolu Local government area of Ogun State where the soil samples in the sites were tested to know the

Contamination, concentration of heavy metals present which constitutes an environmental hazard to

Dumpsites, both human beings and the ecosystem. This was compared with a control that was

Environment taken from an electronic waste free site. The atomic absorption spectrometer (AAS) was used for the analysis and the heavy metals analysed were Cadmium (Cd), Copper $(\mathrm{Cu})$, Chromium (Cr), Zinc (Zn), Nickel (Ni), Lead (Pb), Cobalt (Co), Iron (Fe) and Arsenic (As). Our findings show that zinc and iron exist in the soil at high concentrations. When the data compared with WHO's standard confirmed that Zinc, Iron, and lead are of higher concentration in the samples. However, zinc intake beyond the permissible limits produces toxic effects in the immune system, iron causes nausea and stomach pain while lead causes physical disorders.

\section{APA CITATION}

Odunaike, R. K., Talabi, A. T., Laoye, J. A., Akinyemi, L. P., \& Obasan, M. F. (2022). Assessment of Heavy Metals Contamination of Surface Dust from Waste Electrical and Electronic Equipment at Odogbolu Local Government Area of Ogun State in Southwestern Nigeria. East African Journal of Environment and Natural Resources, 5(1), $22-33$. https://doi.org/10.37284/eajenr.5.1.546 


\section{CHICAGO CITATION}

Odunaike, Rasaki Kolawole, Adetoro Temitope Talabi, John Abidemi Laoye, Lukman Popoola Akinyemi and Mary Feranmi Obasan. 2022. "Assessment of Heavy Metals Contamination of Surface Dust from Waste Electrical and Electronic Equipment at Odogbolu Local Government Area of Ogun State in Southwestern Nigeria". East African Journal of Environment and Natural Resources 5 (1), 22-33. https://doi.org/10.37284/eajenr.5.1.546.

\section{HARVARD CITATION}

Odunaike, R. K., Talabi, A. T., Laoye, J. A., Akinyemi, L. P., \& Obasan, M. F. (2022) “Assessment of Heavy Metals Contamination of Surface Dust from Waste Electrical and Electronic Equipment at Odogbolu Local Government Area of Ogun State in Southwestern Nigeria", East African Journal of Environment and Natural Resources, 5(1), pp. 22-33. doi: 10.37284/eajenr.5.1.546.

\section{IEEE CITATION}

R. K. Odunaike., A. T. Talabi., J. A. Laoye., L. P. Akinyemi., \& M. F. Obasan, “Assessment of Heavy Metals Contamination of Surface Dust from Waste Electrical and Electronic Equipment at Odogbolu Local Government Area of Ogun State in Southwestern Nigeria", EAJENR, vol. 5, no. 1, pp. 22-33, Feb 2022.

\section{MLA CITATION}

Odunaike, Rasaki Kolawole, Adetoro Temitope Talabi, John Abidemi Laoye, Lukman Popoola Akinyemi and Mary Feranmi Obasan. "Assessment of Heavy Metals Contamination of Surface Dust from Waste Electrical and Electronic Equipment at Odogbolu Local Government Area of Ogun State in Southwestern Nigeria". East African Journal of Environment and Natural Resources, Vol. 5, no. 1, Feb 2022, pp. 22-33, doi:10.37284/eajenr.5.1.546.

\section{INTRODUCTION}

Electronic wastes are commonly known as E-waste and are generated from disposed electrical appliances inclusive of but not limited to computers, office electronic equipment/accessories, entertainment devices, mobile phones, television sets and refrigerators (Olafisoye et al., 2013). The increase in the rate of production of electronic gadgets has escalated as a result of the quick evolution of technology, which has rendered older versions of electronics less useful and thereby causing the electronic gadget to be disposed of as electronic waste, resultantly contributing to the pollution of the environment (Ofudje et al., 2014). Atiemo et al. (2012) reported that the rate of production of electronic devices is the fastestgrowing sector of the manufacturing industries in the industrialised countries. In developing countries, electronic waste (E-waste) has become a subject of growing environmental concern due to the legal/illegal import of electronics from developed countries. Newer versions of electronic gadgets and equipment are used to replace obsolete electronic equipment in developed countries and these are creating a major E-waste problem. Of course, uncontrolled disposal has caused various problems such as contamination of groundwater, surface soil, and pollution of the atmosphere due to immediate discharge or surface runoff (Olafisoye et al., 2013). Improper processing of e-waste in developing countries has led to adverse human health effects and environmental pollution. The harmful effect of technological development of electronic industry, especially computer technology, is revealed in the form of polluted drinking water, waste discharges that cause harm to fish, birth defects, high rate of miscarriage and cancer among cluster workers (Zheng et al., 2013).

Electronic waste contains many different substances, some are toxic and others are of high market value when extracted. The improper disposal and poor recycling of precious metals such as gold, copper, and silver also add to the release of toxic metals into the environment which can be risky to the health of individuals. Electronic waste is a heterogeneous mixture of metals, plastics, and ceramics that contains a different percentage of toxic compounds and heavy metals. The contamination of the soil in the E-waste dumpsite is a potential risk to the environment (Li et al., 2011). Olubanjo et al. (2015) discussed that heavy metals like mercury, lead, gallium, selenium, zinc, cobalt, tin, palladium, and aluminium are commonly found in electronic devices. Research on E-waste dumping sites showed that there are harmful metal pollutants in different environments. The contamination of the surface soil by heavy metals is influenced by the spreading of the surface of the soil at the e-waste dumping site (Fujimori \& Takigami, 2014). 


\section{E-WASTE GENERATION IN NIGERIA}

In Nigeria, where environmental enforcement laws may not be enough and are not enforced by appropriate agencies, there is a possibility of a high concentration of heavy metals that can be deposited from electronic waste, thereby causing a widespread environmental hazard to the people and the immediate environment (Olafisoye et al., 2013). It is quite easy to replace an old gadget or damaged electronic equipment with a new one instead of repairing them; hence the damaged ones are dumped indiscriminately. This electronic equipment may contain reusable and valuable components, but in most cases, it contains toxic and hazardous components which make the waste unsafe for the environment. Research has proven that electronic waste leaches the soil due to the presence of heavy metals like mercury, cadmium, lead, and phosphorous in it (Adediran \& Abdulkarim, 2014).
The rate of growth of computers and the fast production of new and advanced electrical appliances has made the rate of dependency on information and technology rise, increasing the demands for advanced gadgets, which has led the environment to a disastrous consequence. The high demands of electronic gadgets are what brought about the increase in electronic waste, making the percentage growth of electronic waste to be alarming. Literature has shown that the volume of electronic waste increases by $3-5 \%$ per year, which is three times more than the growth of domestic waste (Bhoi \& Trupti, 2014). It was recorded by Adaramodu et al. (2012) and Bhoi and Trupti (2014) that the volume of e-waste is increasing by $3-5 \%$ per year. As one of the fast-growing problems of the world, it was estimated that 20-50 million tons of electric and electronic waste are generated per year, of which $75-80 \%$ is shipped to countries in Asia and Africa for recycling and disposal.

Figure 1: Used e-waste dumped in Nigeria displayed for sale

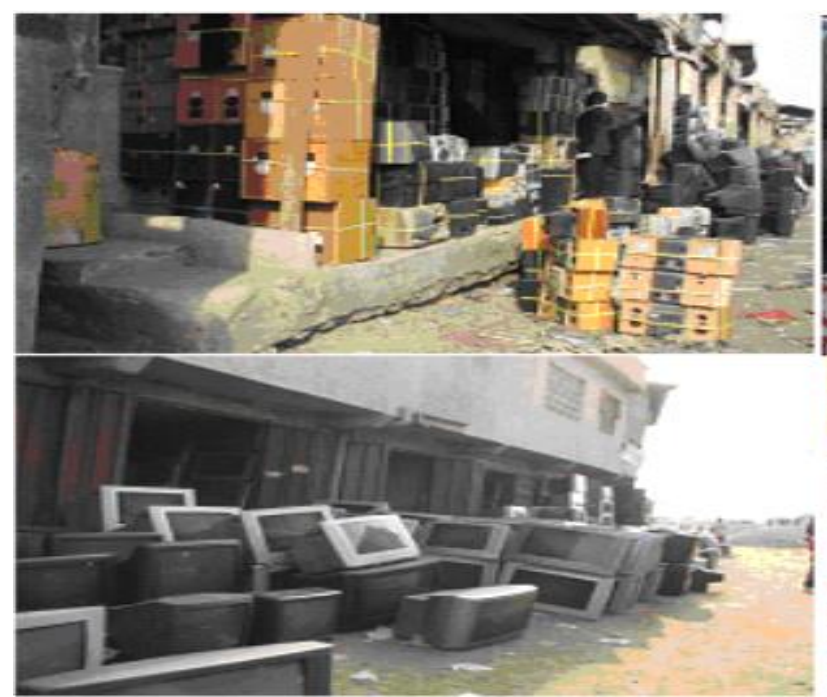

Source: Ogungbuyi et al. (2012)

In developing countries, E-waste has been a subject of major concern as it has been increasing over time; most developed countries have made the developing countries their dumpsite. Obsolete electronic devices are imported into the country both legally and illegally for recycling or destruction. This process is usually not properly monitored in developing countries, thereby exposing the environment and the people to health risks. Developing countries do not have appropriate

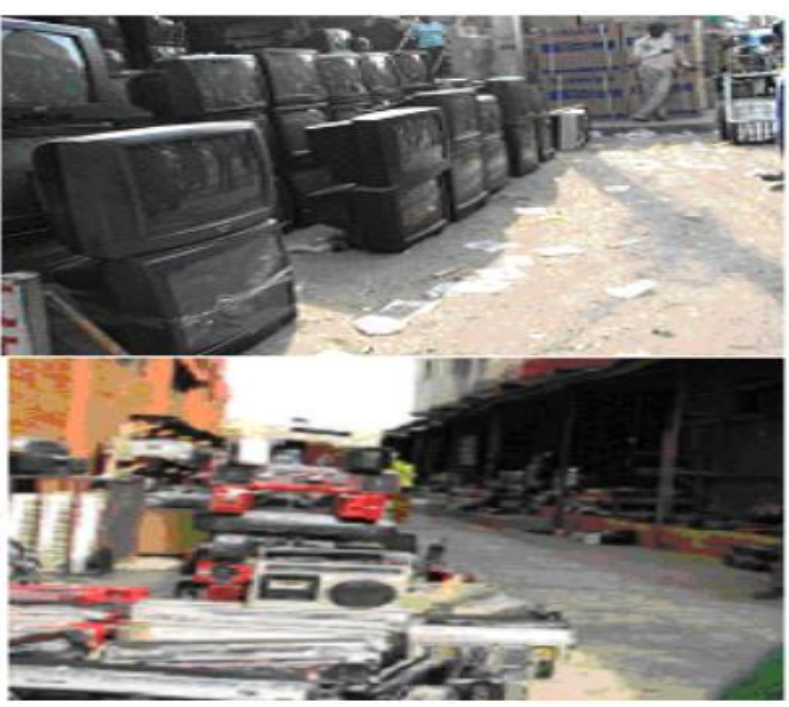

facilities for running the recycling or disposing of processes; hence crude methods are used for this purpose. This unregulated activity of dumping electronic waste has resulted in serious and complex contamination of the environment by toxic chemicals and heavy metals. These metals could expose the people of the community to great health risks through inhalation or even oral intake through contaminated food which can lead to intoxication. Apart from the dangerous effects on humans, it has 
been discovered that electronic waste penetrates the soil due to the presence of mercury, cadmium, lead and phosphorus in it. In addition, uncontrolled burning, disassembly and disposal of electronic waste can cause a variety of environmental problems such as groundwater contamination, atmospheric pollution, and occupational and safety effects among those directly or indirectly involved in the processing of electronic waste.

\section{Aim and Objectives of the Study}

The environmental scientist suggested that the best way to eradicate dumping electronic waste is to have knowledge of what electronic waste contains, its disadvantages and the risk it poses to the environment. This motivated this study with the aim to assess the concentration of heavy metals from electronic waste in our environment with the specific objectives:

Table 1: Effects of E-Waste constituent on health
- To assess the level of some heavy metals at the electronic waste dumpsites in Odogbolu Local government area of Ogun state.

- To identify the harmful effects of electronic waste in our environment.

- To lay emphasis on the fast-rising threat of electronic waste mismanagement on the environment.

This study will bring a clearer view on the havoc caused by electronic waste in the environment, the exposure effects on the soil and the possible damage(s) it could give rise to in the body of individuals see Table 1. It will also help to know the concentration of heavy metals in the soil and to be able to alert the environmentalists and/or their Agencies on the necessary precautions to take to ensure that the environment is conducive for healthy living.

\begin{tabular}{|c|c|c|}
\hline Source of e-wastes & Toxin & Health effects \\
\hline Motherboard & Beryllium & $\begin{array}{l}\text { - Carcinogenic. } \\
\text { - Skin diseases such as warts } \\
\text { - Inhalation of fumes and dust. Causes chronic } \\
\text { beryllium disease or berylliosis. }\end{array}$ \\
\hline $\begin{array}{l}\text { Plastic shield and circuit } \\
\text { boards }\end{array}$ & $\begin{array}{l}\text { Brominated flame } \\
\text { retardants }\end{array}$ & $\begin{array}{l}\text { - Disrupts endocrine system functions. } \\
\text { - Increase in cancer risk. }\end{array}$ \\
\hline $\begin{array}{l}\text { Chip resistors and } \\
\text { semiconductors }\end{array}$ & Cadmium & $\begin{array}{l}\text { - Toxic irreversible effects on human health. } \\
\text { - Accumulates in kidney and liver. } \\
\text { - Causes neural damage. } \\
\text { - Teratogenic. }\end{array}$ \\
\hline $\begin{array}{l}\text { Circuit boards, CRT of } \\
\text { TV, computer monitor, }\end{array}$ & Lead & $\begin{array}{l}\text { - Slow growth in children, hearing problems. } \\
\text { - Diarrhoea, cognition, blindness. } \\
\text { - Behavioural changes. } \\
\text { - Physical disorder. }\end{array}$ \\
\hline $\begin{array}{l}\text { Flat-panel screens, } \\
\text { fluorescent lamps, LCD } \\
\text { monitor, }\end{array}$ & Mercury & $\begin{array}{l}\text { - Emotional changes, tremors, cognition. } \\
\text { - Insomnia, headaches, kidney effects, respiratory } \\
\text { failures, death. } \\
\text { - Impairment of neurological development in } \\
\text { foetuses and small children. }\end{array}$ \\
\hline
\end{tabular}

\section{E-WASTE COMPOSITION}

Ogungbuyi et al. (2012) worked on hazardous materials that were contained in e-waste such as cadmium, beryllium, lead, mercury, and brominated flame-retardants, and these pose both environmental and human health risks. It also contains some valuable metals, such as nickel, iron, aluminium, copper, and precious metals. The precious metals belong to transition elements; they include silver, gold and the platinum-group metals such as 
platinum, iridium, ruthenium, palladium, rhodium, and osmium. Ogungbuyi et al. (2012) described precious metals as metals with beauty, high economic value and particular chemical and physical properties.

Table 2: The valuable metals contained in e-waste products

\begin{tabular}{|c|c|c|}
\hline Products & & Valuable metals \\
\hline TV (CRT monitor) & & $\begin{array}{l}\text { antimony, copper, nickel, gold, silver, platinum, yttrium, } \\
\text { neodymium, aluminium, and iron, }\end{array}$ \\
\hline $\begin{array}{l}\text { Air conditioner, } \\
\text { machine, } \\
\text { Refrigerator }\end{array}$ & Washing & silver, gold, iron, copper, platinum, antimony, and aluminium \\
\hline TV (LCD, plasma) & & $\begin{array}{l}\text { silver, gold, indium, platinum, antimony, yttrium, iron, and } \\
\text { aluminium }\end{array}$ \\
\hline Printed circuit board & & gold, silver, aluminium, tin, and zinc \\
\hline Computer chips & & gold, silver, copper, aluminium, and tin \\
\hline Hard drive & & Platinum, palladium, cobalt, neodymium \\
\hline
\end{tabular}

\section{SOURCES AND GENERATION OF E-WASTE}

The major destination for e-waste from the UK and USA is Nigeria; it costs $\$ 5,000$ USD to ship a $40-\mathrm{ft}$ container full of discarded and used electrical and electronic equipment to Nigeria. Ejiogu (2013) reported that in developing countries such as Nigeria, allied product and computer dealers shipped up to $75 \%$ of electronics to the Computer Village in Ikeja, Lagos, Alaba International Market, and Oshodi Market as irreparable and reparable junk. Since Nigeria has a flourishing market for Act 1988.

The average life cycle of equipment can be calculated using: Average life cycle $=$ Active life + Passive Life + Storage. Where the time span after which the item comes to its end of life is the average life cycle. The active life is the number of years the equipment can be efficiently used, while the Passive life is referred to as the time after Active Life when the equipment can be refurbished or reused. Storage is the time during which the equipment is stored and at repair shops before dismantling (UNEP, 2007). electronics junk as a result of hunger for information and for global IT relevance, the focus is to refurbish or repair the imported used electrical and electronic equipment for re-sale. The toxic waste dumping at Koko created health and environmental hazard in 1988, which then made the federal government establish a body to regulate the importation of hazardous waste (Echenim, 2011; Ejiogu, 2013). The agencies are Federal Solid and Hazardous Waste Management Regulations (1991) and Harmful Waste (Special Criminal Provisions)

In 2019, 54 million metric tons of e-waste were generated worldwide. A few factors such as electronics accessibility have fuelled e-waste generation recently, thereby making it the quickest growing e-waste stream worldwide. This pattern relied upon the projections shown in Figure 2 that by 2030 , e-waste generation would have increased worldwide to approximately $30 \%$. 
Figure 2: Projected electronic waste generation worldwide from 2019 to 2030

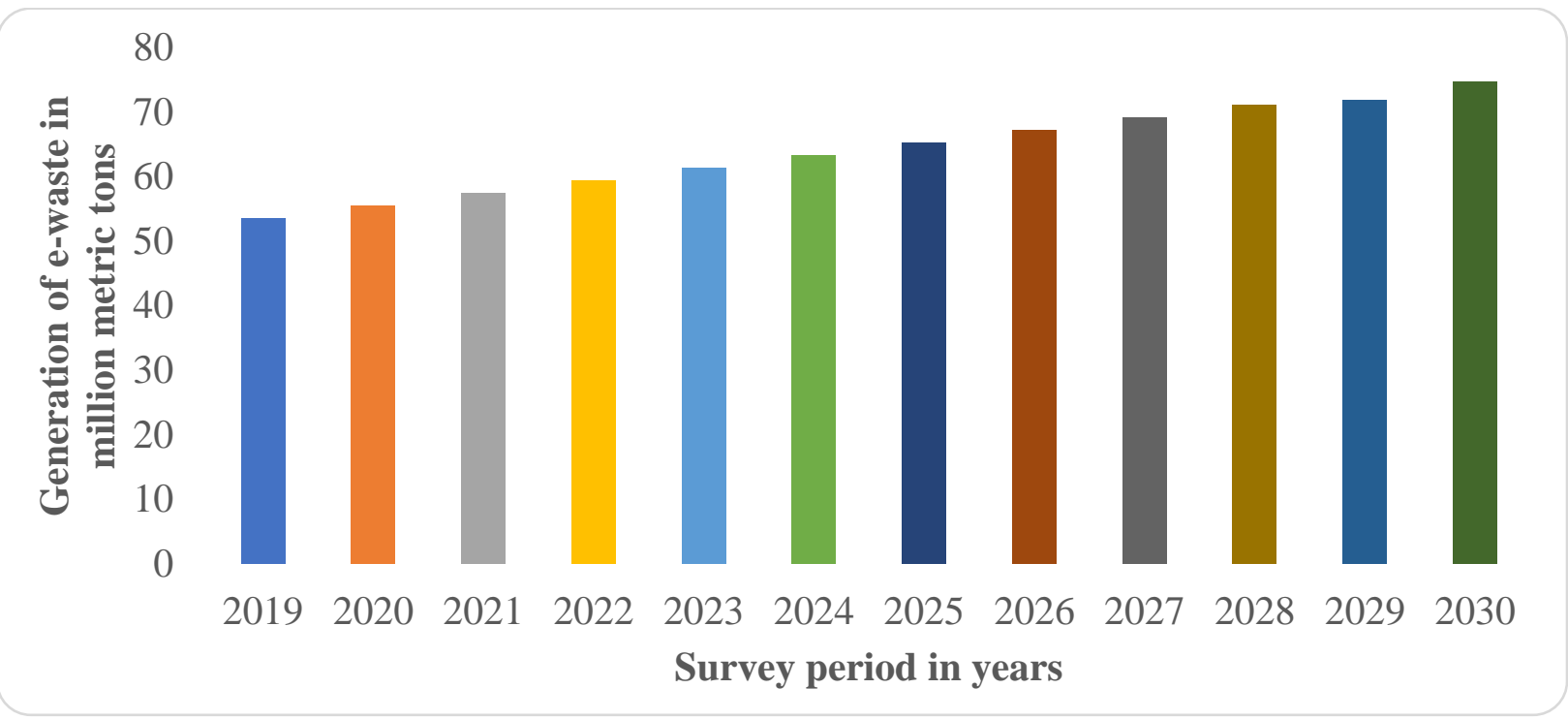

Source: Data adapted from United Nations University

United Nations University (2020) reported that the most e-waste worldwide is produced in Asia; the developed countries produce more e-waste per capita than those in developing countries. For instance, Europe is in excess of 16 kilograms every year; it has the highest per capita rate in terms of total e-waste generation, while in Asia, it is five kilograms, sees Figure 3. In Africa, it is even lower at simply 2.5 kilograms per individual each year; presently, e-waste is a developing environmental concern around the world.

Figure 3: Generation of electronic waste per capita worldwide in 2019 (in Kgs per person)

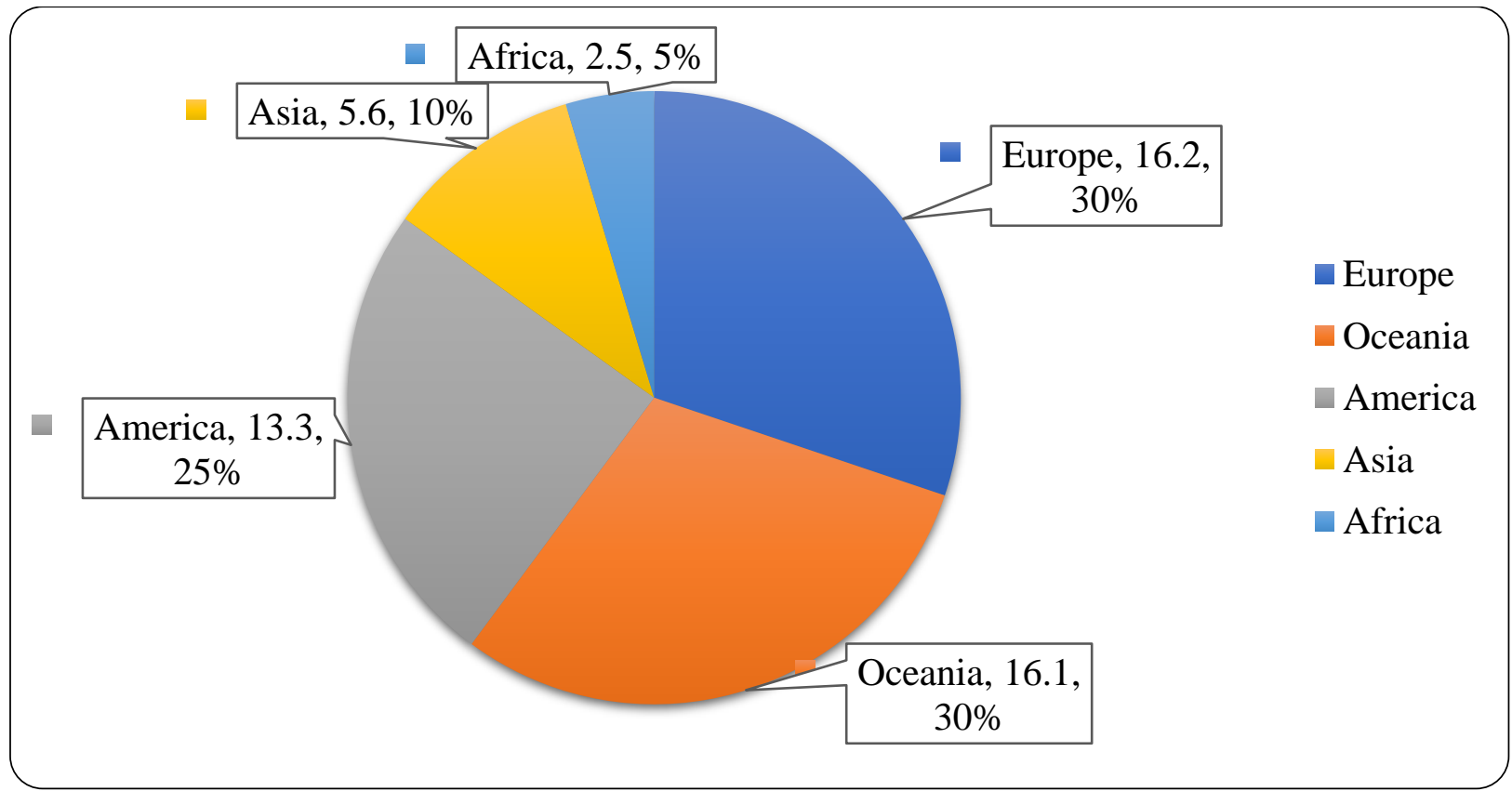

Source: Data adapted from United Nation University (2020). 


\section{MATERIALS AND METHOD}

\section{Study Setting}

The study was carried out in four different locations within Odogbolu town. Odogbolu is domiciled in Ogun State, the South-west geopolitical zone of Nigeria, with a population of 127,123 at the 2006 census and a total area of $541 \mathrm{~km}^{2}$. The local government area shares boundaries with the Ijebu North and Ikene local government and with parts of Lagos state. Farming, hunting and craft-making are important economic activities engaged in by people of the local government. The LGA was created in September 1991 and witnesses two major seasons which are the dry and the rainy seasons with the average humidity level in the area put at 59 per cent. 65.4 per cent own a regular mobile phone, $13 \%$ own televisions, and 48.6 per cent own a radio (NBS, 2019). The local government area lies at $6^{\circ} 50^{\prime} \mathrm{N}$ $3^{\circ} 46^{\prime} \mathrm{E}$ in the northwest of the area, see Figure 4.

\section{Sample Collection/Preparation}

E-waste products from four different locations within the Odogbolu environment were collected and analysed. Soil samples were taken from four different locations within Odogbolu town into bags (Table 3). Each sample collected from dumpsite weighs three grams ( $3 \mathrm{~g})$. A control sample was taken in an environment that is electronic wastefree. The other three samples were taken from sites where electronic wastes were disposed of. Table 3 shows the location, latitude and longitude of the samples collected for the analysis.

Table 3: Dumpsite location

\begin{tabular}{llll}
\hline Sample & Location & Latitude & Longitude \\
\hline A & Odogbolu town hall & $6.84905 \mathrm{~N}$ & $3.77236 \mathrm{E}$ \\
B & Major Market area & $6.83540 \mathrm{~N}$ & $3.76340 \mathrm{E}$ \\
C & Access closa & $6.84221 \mathrm{~N}$ & $3.76497 \mathrm{E}$ \\
Control & Federal government college & $6.86126 \mathrm{~N}$ & $3.77053 \mathrm{E}$ \\
\hline
\end{tabular}

The acquired samples were taken to Geochemistry Laboratory, Central Research Laboratory, University of Lagos, Akoka Lagos State for analysis. Soil samples were weighed (2 g) and then placed into a digestion tube. $10 \mathrm{ml}$ of Aqua regia solution (concentrated Nitric acid \& concentrated Hydrochloric acid) was added to the sample in the digestion tube which was then placed on a Q-block digestion block and digested (heated) for up to (150170) ${ }^{\circ} \mathrm{C}$ for 30 minutes. Digested (heated) sample was allowed to cool for 20-30 minutes and diluted with $25 \mathrm{ml}$ of de-ionised water; the diluted samples solutions were then filtered with the aid of a filter paper into a sample bottle.

\section{Atomic Absorption Spectrometer Analysis}

The Buck Scientific Atomic Absorption Spectrometer Model 210 VGP was used for this analysis.

Principle of operation of Atomic Absorption Spectrometer using flame ionisation detector (FID) requires a liquid sample to be aspirated, aerosolised, and mixed with combustible gases, such as acetylene and air or acetylene and nitrous oxide. The mixture was ignited at temperature ranges from $2100{ }^{\circ} \mathrm{C}$ to $2800{ }^{\circ} \mathrm{C}$ in a flame. During combustion, whereby the light was absorbed in different wavelengths, the atoms of the element of interest in the sample were reduced to free, unexcited ground state atoms. A light beam from a lamp whose cathode was made of the element being determined is passed through the flame to provide elementspecific wavelengths. The amount of reduction of the light intensity due to absorption was detected and this is directly related to the amount of the element in the sample.

A series of standard solutions containing the concentrations of $\mathrm{Cd}, \mathrm{Cu}, \mathrm{Cr}, \mathrm{Zn}, \mathrm{Ni}, \mathrm{Pb}, \mathrm{Co}, \mathrm{Fe}$ and As ions were prepared using deionised distilled water and stock solutions (1000 ppm): 0.00, 0.25, $0.50,1.00,1.50,2.00,3.00$ and $4.00 \mathrm{ppm}$. To obtain accurate quantitative data, the regression coefficient of the standard calibration curve for each element was made greater than 0.9960 . 
Figure 4: A geographical map of the Odogbolu government area
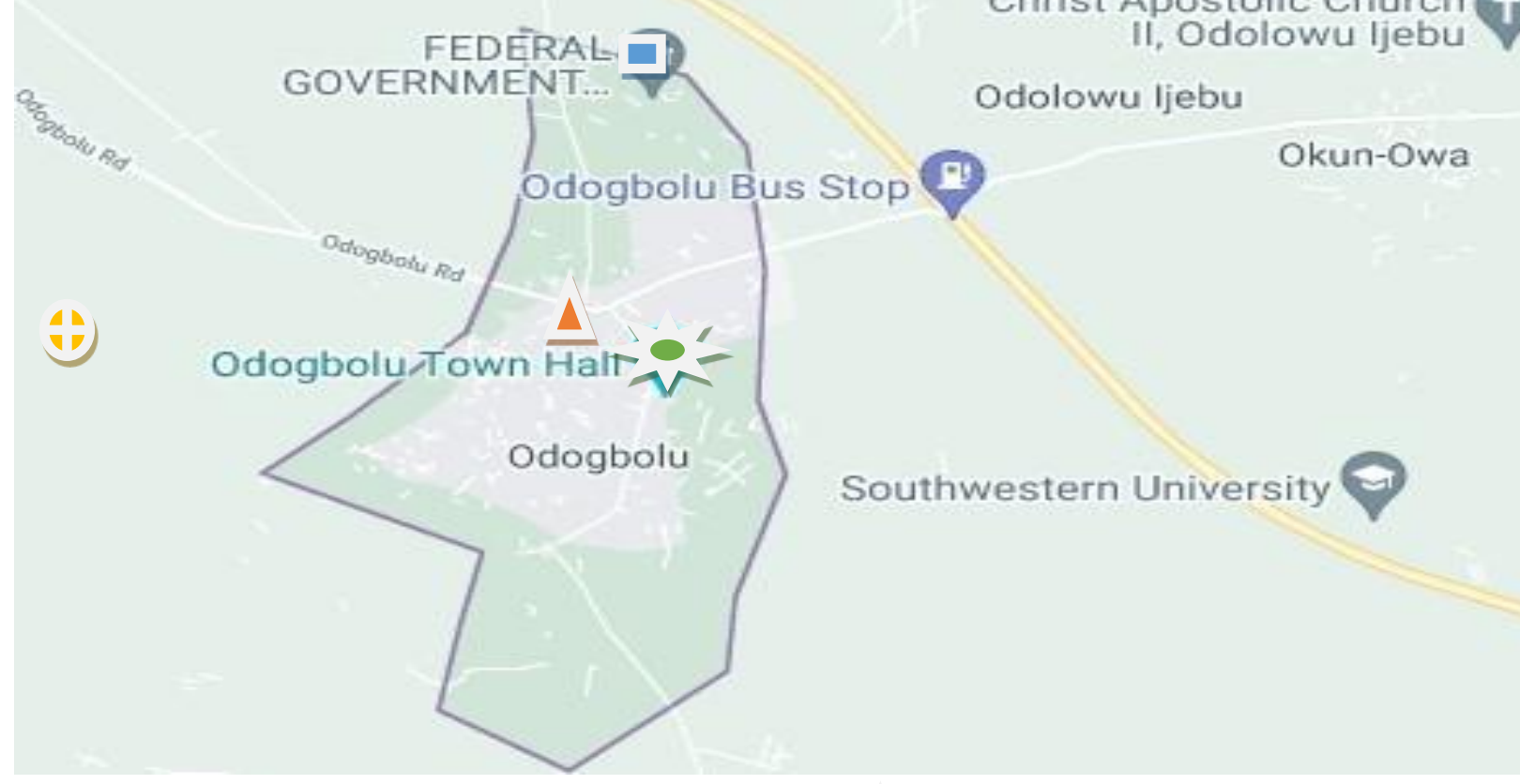

Key: IFederal government college U Access closed $\triangle$ Major Market area $\because-0$ Odogbolu town hall

Source: Google map, 2021

\section{RESULTS AND DISCUSSION}

The results for the examination of heavy metal present in the soil collected at a dumpsite in Odogbolu local government area of Ogun state were depicted in Table 4 in comparison with World Health Organization (WHO, 2011) standards. 
Table 4: Results of analysis of samples collected from the study areas.

\begin{tabular}{|c|c|c|c|c|c|c|c|c|c|}
\hline $\begin{array}{l}\text { Heavy } \\
\text { (mg/kg) }\end{array}$ & metals & $\begin{array}{l}\text { Sample } \\
1(\mathrm{mg} / \mathrm{kg}) \\
\end{array}$ & $\begin{array}{l}\text { Sample } \\
(\mathrm{mg} / \mathrm{kg})\end{array}$ & 2 & $\begin{array}{l}\text { Sample } 3 \\
(\mathrm{mg} / \mathrm{kg})\end{array}$ & $\begin{array}{l}\text { Mean value } \\
(\mathrm{mg} / \mathrm{kg})\end{array}$ & $\begin{array}{l}\text { Control } \\
(\mathrm{mg} / \mathrm{kg})\end{array}$ & $\begin{array}{l}\text { WHO target value of } \\
\text { soil }(\mathrm{mg} / \mathrm{kg})\end{array}$ & $\begin{array}{l}\text { WHO permissible } \\
\text { value of plant }(\mathrm{mg} / \mathrm{kg})\end{array}$ \\
\hline $\mathrm{Cd}$ & & 1.000 & 1.500 & & 0.500 & 1.000 & 0.000 & 0.800 & 0.020 \\
\hline $\mathrm{Cu}$ & & 5.500 & 24.500 & & 0.000 & 10.000 & 2.500 & 36.000 & 10.000 \\
\hline $\mathrm{Cr}$ & & 1.500 & 0.000 & & 0.500 & 0.667 & ND & 100.000 & 1.300 \\
\hline $\mathrm{Zn}$ & & 461.000 & 450.000 & & 674.000 & 528.333 & 183.000 & 50.000 & 0.600 \\
\hline $\mathrm{Ni}$ & & 0.000 & 0.000 & & 0.050 & 0.0167 & ND & 35.000 & 10.000 \\
\hline $\mathrm{Pb}$ & & 8.500 & 43.500 & & 12.500 & 21.500 & 2.000 & 85.000 & 2.000 \\
\hline Co & & 0.015 & 0.063 & & 0.035 & 0.089 & 0.000 & 65.000 & - \\
\hline $\mathrm{Fe}$ & & 385.000 & 300.000 & & 380.000 & 355.000 & 310.000 & 20.000 & 20.000 \\
\hline As & & 0.020 & 0.000 & & 0.000 & 0.007 & ND & 40.000 & - \\
\hline
\end{tabular}

$N D=$ Not detected

Figure 5: Heavy metal concentration of $\mathrm{Cd}, \mathrm{Cr}, \mathrm{Ni}, \mathrm{Co}$ and $\mathrm{As}$

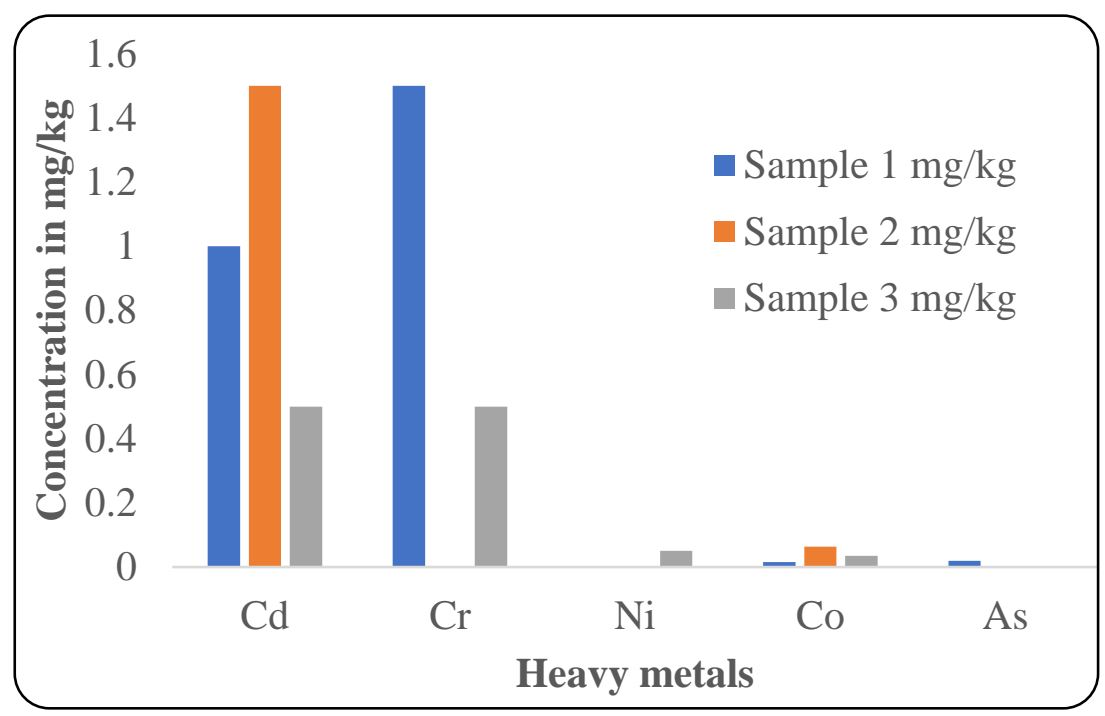

Figure 6: Heavy metal concentration for $\mathrm{Zn}$ and $\mathrm{Fe}$

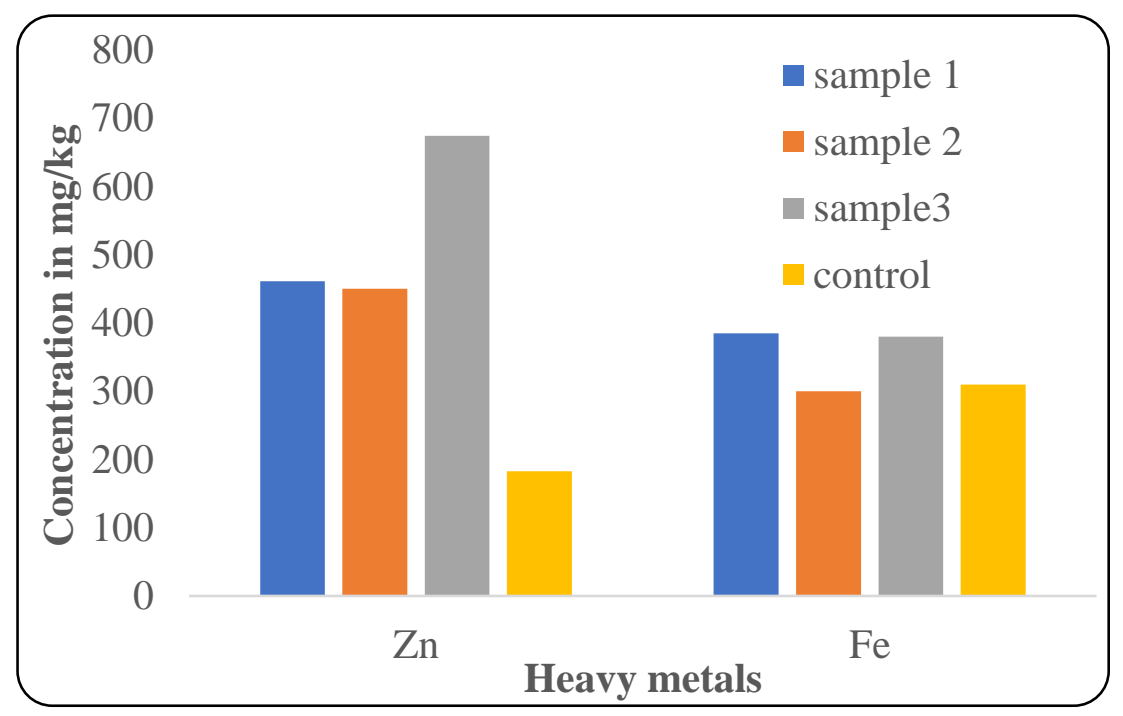


Figure 7: Heavy metal concentration of $\mathrm{Cu}$ and $\mathrm{Pb}$

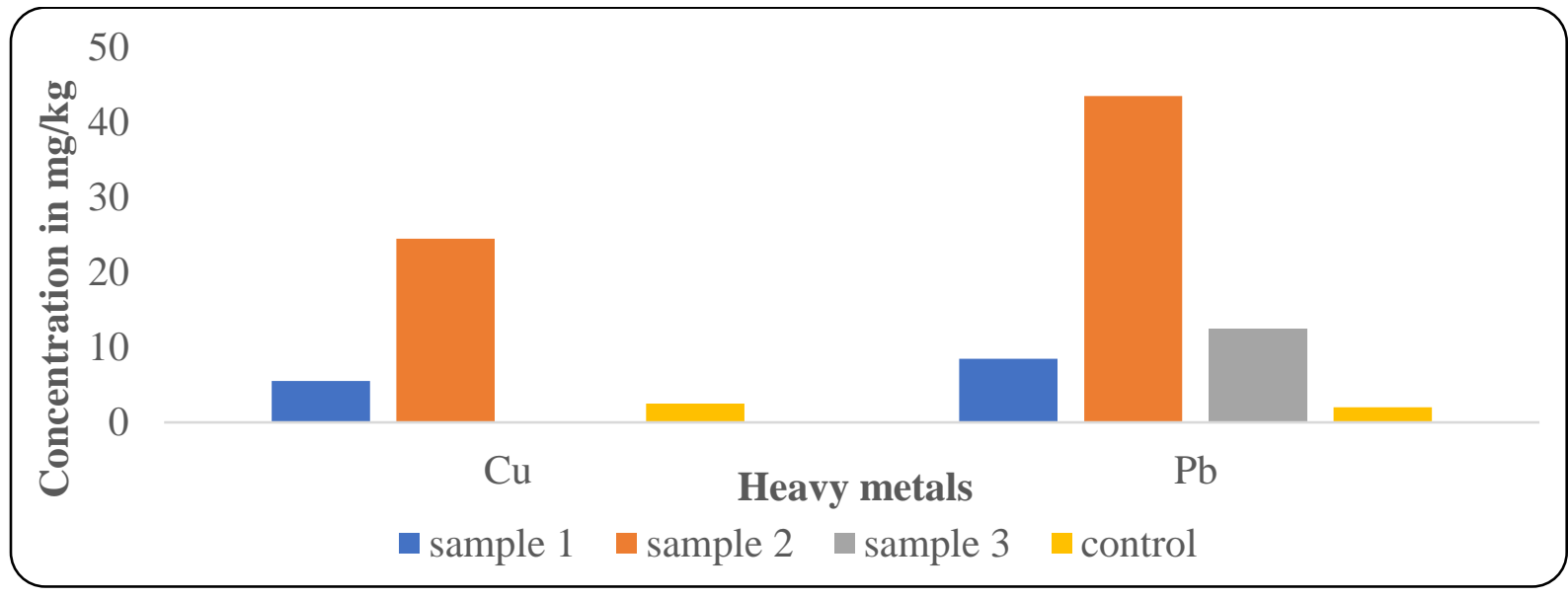

Figure 5 depicts the heavy metal concentration of $\mathrm{Cd}, \mathrm{Cr}, \mathrm{Ni}, \mathrm{Co}$, and As. The concentration of $\mathrm{Cd}$ in the soil samples has a mean value of $1.000 \mathrm{mg} / \mathrm{kg}$, which is above the WHO standard of $0.080 \mathrm{mg} / \mathrm{kg}$. The control sample was $0.000 \mathrm{mg} / \mathrm{kg}$ amount of $\mathrm{Cd}$ while samples 1 and 2 have $\mathrm{Cd}$ present in them at a high range which makes the soil around the environment to be more harmful to human health and also not suitable for plants. This is because chronic ingestion of cadmium can cause kidney disease and bone weakness. Copper $(\mathrm{Cu})$ is an important micro-nutrient in plants but in a small amount to the human diet. The concentration of copper in the soil samples has a mean value of $10.000 \mathrm{mg} / \mathrm{kg}$, which is below the WHO standard of $36.000 \mathrm{mg} / \mathrm{kg}$. Sample 2 has the highest concentration of $\mathrm{Cu}$ present in it, but it is still below the permeable limit of concentration, according to WHO. Chromium $(\mathrm{Cr})$ is toxic to humans and plants in high amounts. WHO standard for chromium in the soil is $100.000 \mathrm{mg} / \mathrm{kg}$, and the amounts detected in the soil samples have a mean value of 0.667 $\mathrm{mg} / \mathrm{kg}$ while it was not detected in the control sample.

Zinc $(\mathrm{Zn})$ is an essential plant nutrient; it is important for the growth of plants. The concentration of $\mathrm{Zn}$ in the samples has a mean value of $528.333 \mathrm{mg} / \mathrm{kg}$, which is much above the WHO standard of $50.000 \mathrm{mg} / \mathrm{kg}$. The high amount of $\mathrm{Zn}$ present in the soil has rendered the soil non-useful for agricultural purposes as too much of $\mathrm{Zn}$ may lead to stunted leaves in plant and interveinal chlorosis. However, the presence of $\mathrm{Zn}$ in the soil in high concentration can accumulate with time to cause bones aorta and kidney issues, liver problems and spleen. It can enter the body through food intake. Nickel (Ni) is also a plant micronutrient; it contributes to nitrogen fixation and is important for seed germination. The WHO standard for $\mathrm{Ni}$ is 35 $\mathrm{mg} / \mathrm{kg}$, and the detected amount of concentration of zinc is very much below the permeable limit as its mean value is $0.0167 \mathrm{mg} / \mathrm{kg}$. Nickel was not detected in the control sample. Lead $(\mathrm{Pb})$ in the samples collected has a mean value of $56.167 \mathrm{mg} / \mathrm{kg}$ which is similarly below the WHO standard of $85.000 \mathrm{mg} / \mathrm{kg}$. A high concentration of $\mathrm{Pb}$ in humans can cause slow growth in children, hearing problems, diarrhoea, cognition, blindness, behavioural changes and physical disorder.

The risk of heavy metals intake through any means is likely to stimulate the immune system and may cause nausea, anorexia, vomiting, gastrointestinal abnormalities and dermatitis (Chuis et al., 2013: Tchounwou et al., 2012). Cobalt (Co) is a trace element in soil and plant. In the collected soil samples, the concentration of Co has a mean value of $0.089 \mathrm{mg} / \mathrm{kg}$, which is below the WHO standard of $65.000 \mathrm{mg} / \mathrm{kg}$.

Figure 6 shows heavy metal concentrations for $\mathrm{Zn}$ and $\mathrm{Fe}$. Iron $(\mathrm{Fe})$ concentration in the acquired soil samples has a mean value of $355.000 \mathrm{mg} / \mathrm{kg}$, which is above the WHO standard of $20 \mathrm{mg} / \mathrm{kg}$. The presence of excess iron in the soil can lead to plant toxicity which can cause bronzing and stippling of leaves. The intake of excess iron into the human body can increase the risk of arthritis, cancer, liver problems, diabetes and heart failure. Arsenic (As) 
concentration in the acquired soil samples as the mean value of $0.007 \mathrm{mg} / \mathrm{kg}$, which is below the WHO standard of $40 \mathrm{mg} / \mathrm{kg}$, As occurs naturally in soil. A high concentration of As can lead to stunted growth of plants. This is in good agreement with the report of Adewumi et al. (2017) that excessive accumulation of heavy metals in soil and other media may eventually contaminate both human and animal food chains.

\section{CONCLUSION}

The level of heavy metals contamination in soil in Odogbolu Local government area of Ogun is higher than the WHO (2011) standard for some metals, particularly iron and zinc. Similarly, the control sample also shows that the environment is highly contaminated with Iron and Zinc, which are higher than WHO standards. This is to conclude that the soil in the environment is not suitable for cultivation due to the high concentration of heavy metals as the plants would surely be contaminated and cause the plant to be toxic and not grow properly. Any farm produces from the soil after cultivation can be of health risk to humans. Therefore, the findings recommend that appropriate laws should be promulgated to guard against heavy metal pollution and to curb improper disposal management of electrical and electronic equipment and accessories. The remediation of polluted areas should be addressed by the Environmental Agencies.

\section{Competing Interests}

The authors declare that they have no known competing financial interests or personal relationships that could have appeared to influence the work reported in this paper.

\section{REFERENCES}

Adaramodu, A. A., Osuntogun, A. O., \& EhiEromosele, C. O. (2012). Heavy Metal Concentration of Surface Dust Present in EWaste Components: The Westminister Electronic Market, Lagos Case Study. Resources and Environment, 2(2), 9-13. https://doi.org/10.5923/j.re.20120202.02

Adediran, Y., \& Abdulkarim, A. (2014). Challenges of electronic waste management in Nigeria.
International Journal of Advances in Engineering \& Technology, 4(1), 640-648.

Adewumi, B., Akingunsola, E., Femi-oloye, O. P., \& Oloye, F. F. (2017). Evaluation of the Heavy Metals Composition of Soil at E-waste Dumping Sites. 5(4), 1- 8. https://doi.org/10.9734/AJEE/ 2017/39500

Atiemo, S. M., Ofosu, F. G., Aboh, I. J. K., \& Kuranchie-Mensah, H. (2012). Assessing the Heavy Metals Contamination of Surface Dust from Waste Electrical and Electronic Equipment (E-waste) Recycling Site in Accra, Ghana Sampson. Research Journal of Environmental and Earth Sciences, 4(5), 605-611. ISSN: 20410492

Bhoi, V. N., \& Shah, T. (2014). E-waste: A New Environmental Challenge. International Journal of Advanced Research in Computer Science and Software Engineering, 4(2), 442-447.

Chuis S., Wong Y. H., Chio H. I., Fong M. et al (2013). Study of Heavy Metals Poisoning infrequent Users of Chinese Medicines in Hong Kong and Macau, Phytother Resp 27, 859-863

Echenim, S. (2011). Lagos leads new partnership on E-waste awareness, The Punch Newspaper, Nigeria, 28 February, www.punchng.com/Articl .aspx?theartic $1 / 4$ Art201102281384573

(Accessed 1st October 2020)

Ejiogu, A. R. (2013). E-waste economics: a Nigerian perspective. Management of Environmental Quality: An International Journal, 24 (2), 199-213. https://doi.org/10.1108/14777831311303083

Fujimori, T., \& Takigami, H. (2014). Pollution distribution of heavy metals in surface soil at an informal electronic-waste recycling site. Environmental Geochemistry and Health, 36(1), 159-168. https://doi.org/10.1007/s10653-0139526-y

Map data (2021). Geographical map of Odogbolu, retrieved from https://www.google.com/maps/ @6.8404044,3.7474106,14z

Li, J., Duan, H., \& Shi, P. (2011). Heavy metal contamination of surface soil in electronic waste

32 This work is licensed under a Creative Commons Attribution 4.0 International License. 
dismantling area: Site investigation and sourceapportionment analysis. Waste Management and Research, 29(7), 727-738. https://doi.org/10.1177/0734242X10397580

NBS (2019). NBS Publishes 2019 General Household Panel Survey Report. https://www.proshareng.com/news/Nigeria\%20 Economy/NBS-Publishes-2019-General Household-Panel-Survey-Report/48271

Ofudje, E. A., Alayande, S. O., Oladipo, G. O., Williams, O. D., \& Akiode, O. K. (2014). Heavy Metals Concentration at Electronic-Waste Dismantling Sites and Dumpsites in Lagos, Nigeria. International Research Journal of Pure and Applied Chemistry, 4(6), 678-690. https://doi.org/10.9734/irjpac/2014/7694

Ogungbuyi, O., Nnorom, I. C., Osibanjo, O. and Schluep, M. (2012). E-Waste Country Assessment Nigeria. E-Waste Africa project of the Secretariat of the Basel Convention pages 194.

Olafisoye, O. B., Adefioye, T., \& Osibote, O. A. (2013). Heavy metals contamination of water, soil, and plants around an electronic waste dumpsite. Polish Journal of Environmental Studies, 22(5), 1431-1439.

Olubanjo, k., Osibanjo, O. and Nnorom, I. C. (2015). Evaluation of $\mathrm{Pb}$ and $\mathrm{Cu}$ contents of selected component parts of waste personal computers. Journal of Applied Sciences and Environmental Management, 19(3), 470-477. ISSN 1119-8362

Tchounwou P. B., Yedjou C. G., Patlolla A. K. and Sutton D. J. (2012). Heavy Metal Toxicity and Environment. EXS 101, 133-164.

UNEP, (2007). E-Waste: Volume I Inventory Assessment Manual. United Nations Environment Protection" 123 pp.

United Nations University (2020). The Global EWaste Monitor 2020, page 24-25. Release July, 2020

WHO (World Health Organization). 2011. Guidelines for drinking water quality, 4th edn.
World Health Organization, Geneva, Switzerland.

Zheng, J., Chen, K. hui, Yan, X., Chen, S. J., Hu, G. C., Peng, X. W., Yuan, J. gang, Mai, B. X., \& Yang, Z. Y. (2013). Heavy metals in food, house dust, and water from an e-waste recycling area in South China and the potential risk to human health. Ecotoxicology and Environmental Safety, 96, 205-212. https://doi.org/10.1016/j.ecoenv. 2013.06.017

33 This work is licensed under a Creative Commons Attribution 4.0 International License. 